\title{
PHOSPHATE FERTILIZATION AND ORGANIC COMPOST ON THE INITIAL GROWTH OF SORGHUM IN DEGRADED SOILS
}

\author{
Edvaldo Renner da Costa Cardoso ${ }^{1 *}$, Francisco Nildo da Silva ${ }^{2}$, Sandra Sely Silveira Maia ${ }^{3}$, Fernando \\ Felipe Ferreyra Hernandez ${ }^{4}$, Rosemery Alesandra Firmino dos Santos ${ }^{1}$, Lailla Sabrina Queiroz Nazareno ${ }^{4}$
}

SAP 24506 Received: 02/04/2020 Accepted: 03/08/2020

Sci. Agrar. Parana., Marechal Cândido Rondon, v. 19, n. 3, jul./sep., p. 289-295, 2020

\begin{abstract}
One of the strategies for the recovery of degraded soils is the planting of fast-growing forage species with high biomass production. In this sense, the objective of this research was to evaluate the initial growth of sorghum in degraded soils with organic fertilization and different phosphorus levels. A completely randomized design with a $4 \times 3 \times 2$ factorial arrangement was used, with four soil types, three levels of phosphorus fertilization and two levels of organic fertilization. At 64 days after sowing the characteristics of the initial growth were analyzed: plant height, stem diameter, leaf number and fresh shoot mass. The height was measured by measuring the neck of the plant until the end of the newest fully expanded leaf, measured with the aid of a measuring tape and expressed in centimeters. The diameter of the stem, by means of a digital pachymeter. The application of phosphorus and organic matter in degraded soils is necessary for the initial development of sorghum plants, due to the low availability of this element, caused by the high adsorption of $\mathrm{P}$ in the soil colloids. Besides that, the lack of organic matter in the studied soils led to a decrease in the growth of sorghum, therefore, it is concluded that soil management in saline environments is necessary for the application of phosphorus and organic matter for a sustainable and technically viable production.
\end{abstract}

Keywords: degraded areas, mineral fertilization, soil management, Sorghum bicolor L.

\section{ADUBAÇÃO FOSFATADA E COMPOSTO ORGÂNICO NO CRESCIMENTO INICIAL DE SORGO EM SOLOS DEGRADADOS}

\begin{abstract}
RESUMO - Uma das estratégias de recuperação de solos degradados é o plantio de espécies forrageiras de rápido crescimento e alta produção de biomassa. Neste sentido, o objetivo dessa pesquisa foi avaliar o crescimento inicial do sorgo em solos degradados, com adubação orgânica e diferentes níveis de fósforo. Foi utilizado delineamento inteiramente casualizado, em arranjo fatorial $4 \times 3 \times 2$, sendo quatro tipos de solos, três níveis de adubação com fósforo e dois níveis de adubação orgânica. Aos 64 dias após a semeadura foram analisadas as características do crescimento inicial: altura da planta, diâmetro do caule, número de folhas e a massa fresca da parte aérea. A altura foi realizada através da medição do colo da planta até o final da folha mais nova totalmente expandida, medida com o auxílio de uma trena e expressa em centímetros. Já o diâmetro do caule, por meio de um paquímetro digital. A aplicação de fósforo e matéria orgânica em solos degradados é necessária para o desenvolvimento inicial das plantas de sorgo, devido à baixa disponibilidade desse elemento, causada pela alta adsorção de $\mathrm{P}$ nos colóides do solo. Além disso, a falta de matéria orgânica nos solos estudados levou a uma diminuição no crescimento do sorgo, portanto, conclui-se que o manejo do solo em ambientes salinos é necessário para a aplicação de fósforo e matéria orgânica para uma produção sustentável e tecnicamente viável.
\end{abstract}

Palavras-chave: Áreas degradadas, adubação mineral, manejo do solo, Sorghum bicolor L.

\section{INTRODUTION}

The amount of degraded soils in the world is increasing, mainly due to the unsustainable practices of current agriculture (ALVES et al., 2012). The large occupation and use of agricultural land bring with its possible environmental impacts caused to the environment, mainly related to soil degradation. Guerra et al. (2010) points out that the State of Ceará has more than 105 municipalities with degraded soils, due to factors such as low rainfall and high evaporative demand (COELHO et al., 2014).
The problem usually arises when irrigation is poorly conducted with the use of inconvenient techniques, resulting in the accumulation of salts in the soil, the intensity of which depends on the quality of the water used for irrigation, the fraction of leaching adopted and the evapotranspirative demand in the region (QIU et al., 2017). As the concentration of these salts increases, the osmotic potential decreases, requiring greater plant energy to absorb water from the soil, thus compromising its development by water stress, regardless of whether the water content in the soil is close to the field capacity (SCHOSSLER et al., 2012).

\footnotetext{
${ }^{1}$ Federal University of Viçosa (UFV), Viçosa, Minas Gerais, Brazil. E-mail: edvaldorcardoso@gmail.com. *Corresponding Author.

${ }^{2}$ University of International Integration of Afro-Brazilian Lusophony (UNILAB), Redenção, Ceará, Brazil.

${ }^{3}$ Federal University of Lavras (UFLA), Lavras, Minas Gerais, Brazil.

${ }^{4}$ Federal University of Ceará (UFC), Fortaleza, Ceará, Brazil.
} 
Phosphorus $(\mathrm{P})$ despite being an essential element in life, in nature it is distributed irregularly. In many regions, $\mathrm{P}$ is limiting agricultural production and periodic additions of $\mathrm{P}$ are necessary in the production of food or fibers (KLEIN; AGNE, 2012). The deficiency of this nutrient in soils usually degraded by salinization is justified by the precipitation of calcium, together with this nutrient, making them unavailable to the plant (CRUZ et al., 2018). In addition, $P$ deficiency is characterized by the strong adsorption of this nutrient in iron and aluminum oxide hydroxides, which occurs in highly weathered soils (GÉRARD, 2016).

In addition to fertilizing with $\mathrm{P}$, it is also common to use organic material, as it helps in the physical restructuring of soils, contributing to the development of plants, due to the presence of its numerous nutrients, particularly nitrogen and phosphorus, small amounts of potassium and other elements, besides allowing the humidity and the balanced temperature, reducing the energy spent by the plant under high temperatures (MIRANDA et al., 2011).

Due to their low cost, improvement in soil structure, greater water retention and maintenance of humidity, organic compounds are widely used in soil management aiming at the recovery of degraded areas because they make possible, above all, the cycling of nutrients through the use of animal waste, for example (WANG et al., 2019). In addition, organic compounds made with bovine manure are generally rich in $\mathrm{P}$, which makes it possible to supply $\mathrm{P}$ to plants with its decomposition (BUSATO et al., 2012).

Sorghum (Sorghum bicolor L.) has both a moderate tolerance to salt stress (COELHO et al., 2014), as well as a high adaptability that allows greater productivity compared to other cereals (PINHEIRO et al., 2018). In this sense, sorghum as a grain is widely used as a raw material for the manufacture of beer, biofuels, food for human and animal consumption, and in the semi-arid tropical regions of sub-Saharan Africa and South Asia, sorghum grain is the staple food in the diet. of the population (ABD EL-MAGEED et al., 2018; CHEN et al., 2019).

The cultivation of sorghum in the northeastern semiarid has characteristics of adaptation such as tolerance to water deficiencies, high temperatures, irregular rainfall distribution and the most varied soil fertility conditions (ANDRADE NETO et al., 2010). In this sense, the objective of the work was to evaluate the initial growth of sorghum in degraded soils, with organic fertilization and different levels of phosphorus.

\section{MATERIAL AND METHODS}

The study was carried out at the Federal University of Ceará (UFC), Campus Pici, in the city of Fortaleza (Ceará State, Brazil), located at 3\%45'47' and $38^{\circ} 31^{\prime} 23$ " and an average altitude of $47 \mathrm{~m}$. The experiment was conducted in a greenhouse belonging to the UFC's Soil Science Department. The soils used in the experiment were collected in the region of Baixo
Jaguaribe, in the municipalities of Russas, Quixeré, Limoeiro do Norte, Tabuleiro do Norte and Morada Nova. This region of Ceará is an important pole of economic development through irrigated fruit and shrimp farming, with soils degraded by salinization (CUNHA et al., 2014).

The soil samples were collected at a depth of 0-20 $\mathrm{cm}$ from four different points, in order to obtain a composite sample for each municipality. The samples were air dried, ground and passed through a sieve with $2 \mathrm{~mm}$ mesh (TFSA). Subsequently, physical and chemical analyzes of soil samples were performed according to the methods described by Embrapa (EMBRAPA, 1997). The chemical characterization of the soil was done through the $\mathrm{pH}$ in $\mathrm{H}_{2} \mathrm{O}$, exchangeable bases, assimilable phosphorus and exchangeable aluminum. The physical characterization of the soil was carried out through the electrical conductivity of the soil solution. Soil classification was carried out according to the criteria established in accordance with the Brazilian Soil Classification System (SANTOS et al., 2018).

The seeds of forage sorghum were acquired in a commercial establishment and were planted in plastic pots with a capacity of $2 \mathrm{~kg}$ of substrate per pot. Six seeds were sown equidistantly in each pot. After emergence, thinning was carried out, leaving only two plants per pot. All treatments were irrigated whenever necessary with tap water, with the humidity of the substrate in the pots kept close to $60 \%$ of the total volume of soil pores, calculating the field capacity of each soil and providing approximately $60 \%$ corresponding water volume.

The experiment was carried out following a completely randomized design, for treatments in a $4 \times 2 \times 3$ factorial arrangement (four soils, two doses of organc compost and three doses of phosphorus) and four replications, totaling 96 experimental units (pots). The seeds of forage sorghum were acquired in a commercial establishment and were planted in plastic pots with a capacity of $2 \mathrm{~kg}$ of substrate per pot. Six seeds were sown equidistantly in each pot. After emergence, thinning was carried out, leaving only two plants per pot. All treatments were irrigated whenever necessary with tap water, with the humidity of the substrate in the pots kept close to $60 \%$ of the total volume of soil pores, calculating the field capacity of each soil and providing approximately $60 \%$ corresponding water volume.

Phosphorus fertilization was carried out using phosphoric acid as the source, taking as a recommended dose $0.5 \mathrm{~g}$ of $\mathrm{P}$ (phosphoric acid) per plant according to the amount of this nutrient in the soil. Thereafter, the doses used consisted of control treatment (without application of P), treatment with the recommended dose and treatment with twice the recommended dose. At 64 days after sowing, plant height, stem diameter, number of leaves, leaf length and fresh mass of the aerial part were analyzed. The height was measured by measuring the neck of the plant until the end of the youngest fully expanded leaf, measured with the aid of a measuring tape and expressed in centimeters, while in the stem diameter a digital pachymeter was used. 
The data obtained from the evaluated characteristics were subjected to analysis of variance by the $\mathrm{F}$ test and when found significant results, the means of each treatment were compared using the Tukey test at 5\% probability, using the statistical package ASSISTAT version 7.7 beta (SILVA, 2014), with subsequent unfolding for significant results.

\section{RESULTS AND DISCUTION}

The analyzed attributes of the studied soils are shown in Table 1. The soils were classified as: soil 1 (S1) = Molisol, soil 2 (S2) = Inceptisol, soil 3 (S3) = Alfisol and soil $4(\mathrm{~S} 4)=$ Entisol. Regarding the phosphorus contents, it was found that they are relatively low, and in S2 and S3, the contents were higher. Gérard (2016) claim that tropical soils have high phosphorus fixation, which decreases their availability for plants.

Soil $\mathrm{pH}$ less than 5 have a higher occurrence of phosphorus bound to the mineral containing iron and aluminum. At a $\mathrm{pH}$ greater than 7 , the occurrence is greater in minerals that contain calcium, and the $\mathrm{pH}$ variation can promote the dissolution of these minerals and the formation of other compounds with phosphorus. According to the analysis of variance (ANAVA), it appears that there were significant differences for most of the variables analyzed (Table 2 ).

TABLE 1 - Chemical characteristics of the studied soils.

\begin{tabular}{|c|c|c|c|c|c|c|c|}
\hline \multirow{2}{*}{ Soils } & \multirow{2}{*}{$\mathrm{pH}$} & $\mathrm{Ca}$ & $\mathrm{Mg}$ & $\mathrm{K}$ & $\mathrm{Al}$ & \multirow{2}{*}{$\begin{array}{c}\mathrm{P} \\
\left(\mathrm{mg} \mathrm{kg}^{-1}\right)\end{array}$} & \multirow{2}{*}{ 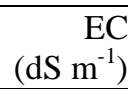 } \\
\hline & & -------- & ------- & & - & & \\
\hline $\mathrm{S} 1$ & 8.11 & 25.13 & 11.10 & 1.26 & 0.72 & 1.12 & 0.28 \\
\hline $\mathrm{S} 2$ & 5.64 & 0.97 & 1.70 & 0.22 & 0.90 & 7.46 & 0.19 \\
\hline S3 & 4.96 & 0.66 & 1.40 & 0.09 & 0.43 & 4.30 & 0.22 \\
\hline S4 & 7.54 & 8.49 & 4.58 & 1.45 & 0.62 & 1.03 & 0.24 \\
\hline
\end{tabular}

$\mathrm{Ca}=$ calcium, $\mathrm{Mg}=$ magnesium, $\mathrm{K}=$ potassium, $\mathrm{Al}=$ aluminum, $\mathrm{P}=$ phosphor, $\mathrm{EC}=$ electric conductivity.

The same way, there was a significant interaction between soils and levels of organic material, soils and phosphorus doses, as well as between the three factors together, showing that the effects of these factors depend on each other. Phosphorus adsorption capacity increases in depth that increases, due to facts of depth and contents of materials of plant origin that are inversely proportioned measures, that is, the greater the depth, the less or the content of organic matter and the greater the content of oxides and hydroxides of Fe and Al (GÉRARD, 2016).

TABLE 2 - Shows ANAVA summary for, number of leaves (NL), plant height (PH) (cm), stem diameter (SD) (mm) and fresh mass of aerial part (FMAP) (g) of sorghum in degraded soils cultivated with doses of phosphorus and organic matter.

\begin{tabular}{|c|c|c|c|c|c|}
\hline \multirow{2}{*}{ VSource } & \multirow{2}{*}{ LD } & \multicolumn{4}{|c|}{ MS } \\
\hline & & $\mathrm{PH}$ & $\mathrm{NL}$ & SD & FMAP \\
\hline$\overline{\mathrm{F} 1}$ & 3 & $499,28022 * *$ & $499,28022 * *$ & $499,28022 * *$ & $499,28022 * *$ \\
\hline $\mathrm{F} 2$ & 1 & $3218,02531 * *$ & $3218,02531 * *$ & $3218,02531 * *$ & $3218,02531 * *$ \\
\hline F3 & 2 & $1372,05698 * *$ & $1372,05698 * *$ & $1372,05698 * *$ & $1372,05698 * *$ \\
\hline $\mathrm{F} 1 \times \mathrm{F} 2$ & 3 & $173,07513 *$ & $173,07513 *$ & $173,07513 *$ & $173,07513 *$ \\
\hline $\mathrm{F} 1 \times \mathrm{F} 3$ & 6 & 381,23439 ** & $381,23439 * *$ & $381,23439 * *$ & $381,23439 * *$ \\
\hline $\mathrm{F} 2 \times \mathrm{F} 3$ & 2 & $943,66156 * *$ & $943,66156 * *$ & $943,66156^{* *}$ & $943,66156 * *$ \\
\hline $\mathrm{F} 1 \times \mathrm{F} 2 \times \mathrm{F} 3$ & 6 & $703,97971 * *$ & $703,97971 * *$ & $703,97971 * *$ & $703,97971 * *$ \\
\hline ERRO & 48 & & & & \\
\hline $\mathrm{CV}(\%)$ & & 9,62 & 14,43 & 11,77 & 27,83 \\
\hline
\end{tabular}

F1 = types of soils, F2 = organic matter (compost), F3 = doses of phosphorus, *, ** = respectively significant at $5 \%$ and $1 \%$ probability by the Tukey's test. Vsource $=$ variation source, $\mathrm{DL}=$ degree of liberty, $\mathrm{MS}=$ medium $\operatorname{square}, \mathrm{CV}(\%)=\operatorname{coefficient}$ of variation.

The presence of organic matter in the soil tends to decrease phosphorus adsorption, because its decomposition releases organic acids. These acids have a certain affinity for phosphorus adsorption sites, causing the adsorption of this nutrient to decrease and consequently increasing its availability to plants (ANDRADE et al., 2003). Table 3 shows the averages obtained for each factor in isolation.

For plant height characteristics, S2 was the one with the best results, differing statistically only from S1 and S4. It was also observed that this same soil also showed superior results for stem diameter and fresh mass characteristics. aerial part, which can be justified by the higher levels of phosphorus found in it. In addition, this same soil showed the best $\mathrm{pH}$ in relation to the others, which may have improved the availability and absorption of other nutrients. Regarding the number of leaves, only soil 1 differed statistically from the others, with a lower average. 
TABLE 3 - Comparison of means for the following factors: soil, organic matter and doses of phosphorus for the analyzed variables of the initial growth of sorghum in degraded soils cultivated with doses of phosphorus and organic matter.

\begin{tabular}{|c|c|c|c|c|}
\hline Variation Source & $\mathrm{PH}(\mathrm{cm})$ & $\mathrm{SD}(\mathrm{mm})$ & NL & FMAP $(\mathrm{g})$ \\
\hline \multicolumn{5}{|c|}{ Factor 1 - types of soils } \\
\hline$\overline{\mathrm{S} 1}$ & $67.59 b^{*}$ & $5.99 \mathrm{~b}$ & $2.86 \mathrm{~b}$ & $9.36 \mathrm{~b}$ \\
\hline S2 & $74.03 \mathrm{a}$ & $7.00 \mathrm{a}$ & $3.44 \mathrm{a}$ & $12.86 \mathrm{a}$ \\
\hline S3 & $69.09 \mathrm{ab}$ & $5.88 \mathrm{~b}$ & $3.50 \mathrm{a}$ & $8.11 \mathrm{bc}$ \\
\hline S4 & $61.25 \mathrm{c}$ & $5.85 \mathrm{~b}$ & $3.36 \mathrm{a}$ & $6.40 \mathrm{c}$ \\
\hline \multicolumn{5}{|c|}{ Factor 2 - organic matter } \\
\hline Without OM* & $61.30 \mathrm{~b}$ & $5.58 \mathrm{~b}$ & $3.11 \mathrm{~b}$ & $7.54 \mathrm{~b}$ \\
\hline With OM & $74.68 \mathrm{a}$ & $6.79 \mathrm{a}$ & $3.47 \mathrm{a}$ & $10.83 \mathrm{a}$ \\
\hline \multicolumn{5}{|c|}{ Factor 3 - doses of phosphorus (P) } \\
\hline $0 \% \mathrm{P}$ & $59.66 \mathrm{~b}$ & $5.51 \mathrm{~b}$ & $3.65 \mathrm{a}$ & $8.15 \mathrm{~b}$ \\
\hline $100 \% \mathrm{P}$ & $69.89 \mathrm{a}$ & $6.45 \mathrm{a}$ & $2.96 \mathrm{~b}$ & $9.25 \mathrm{ab}$ \\
\hline $200 \% \mathrm{P}$ & $74.42 \mathrm{a}$ & $6.59 \mathrm{a}$ & $3.27 \mathrm{~b}$ & $10.17 \mathrm{a}$ \\
\hline
\end{tabular}

*Averages followed by the same capital letter, do not differ statistically (Tukey, p>0,05). PH = plant height, SD = stem diameter, $\mathrm{NL}=$ number of leaves, FMAP = fresh mass of the aerial part, $\mathrm{OM}=$ organic matter (compost).

In general, the addition of organic matter provided an increase in the averages of all analyzed variables. This fact can be explained by the influence that organic matter has on the physical characteristics of the soil, improving its texture and structure. In addition to providing better physical characteristics of the soil, it was also visually observed that soils without the presence of organic matter (B) negatively influenced the emergence of sorghum plants (Figure 1). Andrade et al. (2003) affirm that the addition of organic matter decreases the adsorption of $\mathrm{P}$ and influences soil moisture, thus improving the availability of this and other nutrients in the soil solution.

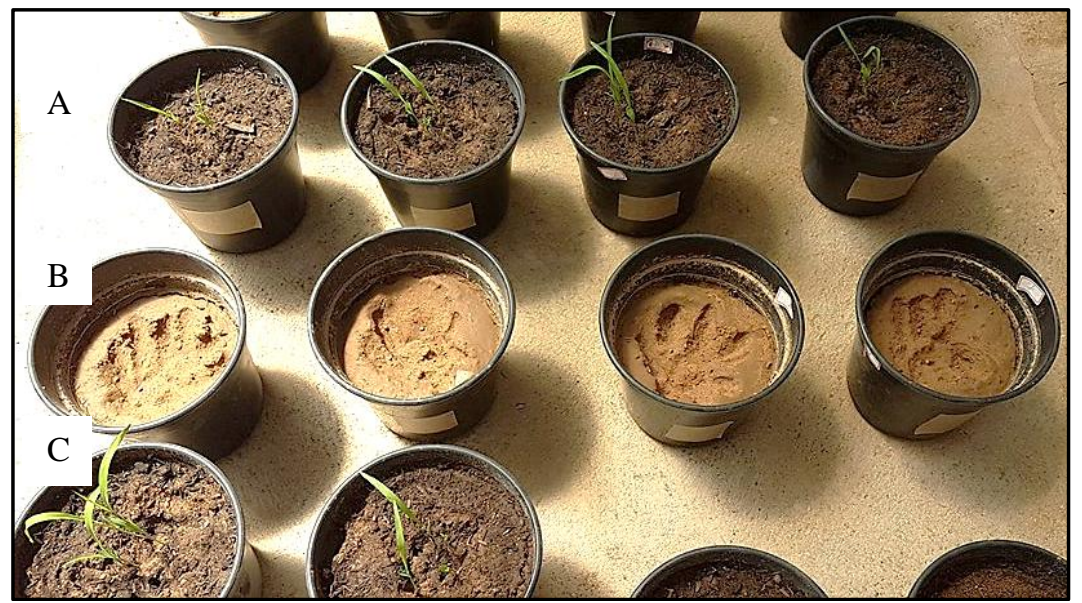

FIGURE 1 - Influence of organic matter on seedling emergence. A and C - with the presence of organic matter, B - without the presence of organic matter. Source: The authors.

Regarding the doses of $\mathrm{P}(0 \%, 100 \%$ and $200 \%)$, for the variables plant height, a fresh mass of the aerial part and stem diameter, there was an increase in the averages as the phosphorus doses were increased. Santos et al. (2016) state that phosphorus plays an important role in the performance and growth of plants in the Poaceae family, since it is the main component of important compounds in plant cells, in addition to mediating the process of respiration and photosynthesis. These results are in line with those found by Parente et al. (2014) that when working with increasing doses of phosphorus in the sorghum crop, found higher averages of plant height and stem diameter as the $\mathrm{P}$ dose increased.

On the other hand, a higher average was observed for the number of leaves in the treatment with $0 \%$ phosphorus, that is, without the application of this nutrient. This fact may have occurred possibly because the increase in the phosphorus content in the soil caused an adverse effect on the assimilation of other nutrients, namely $\mathrm{N}$ and $\mathrm{Zn}$. In addition to having fundamental participation in the metabolism of $\mathrm{N}$ (aiming to promote increases in plant production), because, according to Novais et al. (2016), they claim that although there are controversies regarding the interaction between $\mathrm{P}$ and $\mathrm{Zn}$, in very high concentrations of the first, there is a decrease in the second, especially in the aerial part of the plants.

In the first interaction (Table 4), for plant height, it was observed that, in general, the increase in the dose of $\mathrm{P}$ provided improvement in the results, with the highest dose $(200 \%)$ responsible for the highest averages. 
Regarding soils, it is noted that in the absence of fertilization with $\mathrm{P}, \mathrm{S} 2$ showed better results for this variable, differing statistically from $\mathrm{S} 1$, which can be explained by the higher $\mathrm{P}$ content than $\mathrm{S} 2$ has, in addition of presenting a $\mathrm{pH}$ range that better favors the availability and absorption of other nutrients, although $\mathrm{S} 1$ has a higher content of exchangeable bases. Thus, it can be said that, except for S3, P deficiency significantly limited plant height. Silveira et al. (2018) testing the effects of phosphate fertilization on grain sorghum, found a significant increase both in the dry matter of the aerial part and and $\mathrm{P}$ accumulation in treatments with higher SS proportions, leading to higher agronomic efficiency (AEI). An interesting fact occurred for the variable number of leaves, where S2 and S4 showed a decrease in the averages of this variable due to the increase in the dose of $\mathrm{P}$.

In the case of $\mathrm{S} 2$, because it has a higher content of $\mathrm{P}$, the addition of this nutrient in the recommended dose may have caused adsorption or immobilization of the nutrient or some effect of toxicity. However, when the dose was increased to twice the recommended dose, an increase in the average was observed, which can be explained by the fact that the increase in the dose caused mineralization of this nutrient (Table 4).

According to Possamai et al. (2014), the inadequate supply of phosphorus in forage grasses reduces the leaf area, the number of leaves, and consequently, the rate of photosynthesis. On the other hand, S4, the addition of phosphorus was permanently negative, and the treatment without addition of $\mathrm{P}$ differed statistically from treatments with addition in the recommended dose and twice the recommended dose. According to Carstensen et al. (2018), phosphorus deficiency in plants is not as striking, or very expressive, as with other nutrients, however, it is due to the deficiency of this nutrient, a marked reduction in plant growth.

TABLE 4 - Doses of phosphorus $(\mathrm{P})$ doses on the variables analyzed for each of the four soil samples.

\begin{tabular}{|c|c|c|c|}
\hline \multirow{2}{*}{ Types of soils } & \multicolumn{3}{|c|}{ Doses of phosphorus (P) } \\
\hline & $0 \%$ & $100 \%$ & $200 \%$ \\
\hline \multicolumn{4}{|c|}{ Plant height $(\mathrm{cm})$} \\
\hline $\mathrm{S} 1$ & $46.05 \mathrm{cB}^{*}$ & $76.75 \mathrm{aA}$ & $79.97 \mathrm{aA}$ \\
\hline $\mathrm{S} 2$ & $72.50 \mathrm{aAB}$ & $70.00 \mathrm{abB}$ & $79.58 \mathrm{aA}$ \\
\hline S3 & $64.47 \mathrm{abA}$ & $70.00 \mathrm{abA}$ & $72.13 \mathrm{bA}$ \\
\hline S4 & $55.63 \mathrm{bcB}$ & $62.13 \mathrm{bAB}$ & $66.00 \mathrm{bA}$ \\
\hline \multicolumn{4}{|c|}{ Stem diameter $(\mathrm{mm})$} \\
\hline S1 & $4.31 \mathrm{cB}$ & $6.53 \mathrm{aA}$ & $7.14 \mathrm{aA}$ \\
\hline $\mathrm{S} 2$ & $7.07 \mathrm{aAB}$ & $6.31 \mathrm{aB}$ & $7.62 \mathrm{aA}$ \\
\hline S3 & $5.47 \mathrm{bA}$ & $6.44 \mathrm{aA}$ & $5.74 \mathrm{bA}$ \\
\hline S4 & $5.17 \mathrm{bcB}$ & $6.51 \mathrm{aA}$ & $5.86 \mathrm{bAB}$ \\
\hline \multicolumn{4}{|c|}{ Number of leaves } \\
\hline S1 & $2.75 \mathrm{bA}$ & $2.75 \mathrm{aA}$ & $3.08 \mathrm{aA}$ \\
\hline $\mathrm{S} 2$ & $4.00 \mathrm{aA}$ & $2.75 \mathrm{aB}$ & $3.58 \mathrm{aA}$ \\
\hline S3 & $3.83 \mathrm{aA}$ & $3.17 \mathrm{aB}$ & $3.50 \mathrm{aAB}$ \\
\hline $\mathrm{S} 4$ & $4.00 \mathrm{aA}$ & $3.17 \mathrm{aB}$ & $2.92 \mathrm{aB}$ \\
\hline \multicolumn{4}{|c|}{ Fresh mass of aerial part $(\mathrm{g})$} \\
\hline S1 & $5.67 \mathrm{bB}$ & $9.92 \mathrm{abA}$ & $12.51 \mathrm{aA}$ \\
\hline $\mathrm{S} 2$ & $14.27 \mathrm{aA}$ & $11.80 \mathrm{aA}$ & $12.50 \mathrm{aA}$ \\
\hline S3 & $7.48 \mathrm{bA}$ & $8.27 \mathrm{abA}$ & $8.61 \mathrm{abA}$ \\
\hline S4 & $5.18 \mathrm{bA}$ & $7.00 \mathrm{bA}$ & $7.01 \mathrm{bA}$ \\
\hline
\end{tabular}

*Averages followed by the same letter in the column, do not differ statistically by the Tukey's test $(p \leq 0,05)$. Capital letters in the lines, compare the doses of $\mathrm{P}$ for each soil, lowercase letters in the columns, compare the averages obtained for each soil.

Table 5 shows the interaction between each soil and organic matter, where it can be seen that at least for the plant height variable, the addition of $\mathrm{OM}$ in the soil caused a significant increase for the variable in question for all four soils. Liang et al. (2019) highlight the importance of organic matter due to its great contribution power in the negative loads of soils in tropical regions. Regarding the stem diameter, the pattern for significant difference between treatments, where the without the addition remained to cause all soils, except for soil 4 which did not show statistical difference between treatments.
The increase in organic matter was also present for the number of leaves in S1 and S2, and in the FMAP in S1 and S3. S3 and S4 did not show any significant difference for the number of leaves, and equally, S2 and S4 for FMAP, with little influence of organic matter in the S4. Santos et al. (2016) working with different sources of fertilization and use of mulch in forage sorghum, obtained higher average for leaf and stem characteristics in treatments without fertilization and without mulch, justified by the characteristics of the cultivar used. Thus, future work involving different sorghum varieties and even testing soil salinity levels, should be able to consolidate the 
response of that crop with respect to the influence of

phosphorus and organic matter.

TABLE 5 - Organic matter on the variables analyzed for each of the four soil samples.

\begin{tabular}{|c|c|c|}
\hline \multirow{2}{*}{ Types of soils } & \multicolumn{2}{|c|}{ Organic matter } \\
\hline & With organic matter & Without organic matter \\
\hline & \multicolumn{2}{|c|}{ Planta height $(\mathrm{cm})$} \\
\hline$\overline{\mathrm{S} 1}$ & $56.48 \mathrm{bB}^{*}$ & $78.70 \mathrm{aA}$ \\
\hline S2 & $70.11 \mathrm{aB}$ & $77.94 \mathrm{aA}$ \\
\hline S3 & $62.90 \mathrm{abB}$ & $75.28 \mathrm{aA}$ \\
\hline \multirow[t]{2}{*}{ S4 } & $55.73 \mathrm{bB}$ & $66.78 \mathrm{bA}$ \\
\hline & \multicolumn{2}{|c|}{ Stem diameter $(\mathrm{mm})$} \\
\hline$\overline{\mathrm{S} 1}$ & $4.91 \mathrm{bB}$ & $7.08 \mathrm{abA}$ \\
\hline $\mathrm{S} 2$ & $6.48 \mathrm{aB}$ & $7.53 \mathrm{aA}$ \\
\hline S3 & $5.33 \mathrm{bB}$ & $6.44 \mathrm{bcA}$ \\
\hline \multirow[t]{2}{*}{ S4 } & $5.60 \mathrm{abA}$ & $6.10 \mathrm{cA}$ \\
\hline & \multicolumn{2}{|c|}{ Number of leaves } \\
\hline$\overline{\mathrm{S} 1}$ & $2.61 \mathrm{bB}$ & $3.11 \mathrm{bA}$ \\
\hline S2 & $3.00 \mathrm{abB}$ & $3.89 \mathrm{aA}$ \\
\hline S3 & $5.50 \mathrm{aA}$ & $3.50 \mathrm{abA}$ \\
\hline \multirow[t]{2}{*}{ S4 } & $3.33 \mathrm{aA}$ & $3.39 \mathrm{abA}$ \\
\hline & \multicolumn{2}{|c|}{ Fresh mass of aerial part $(\mathrm{g})$} \\
\hline$\overline{\mathrm{S} 1}$ & $6.57 \mathrm{bB}$ & $12.16 \mathrm{abA}$ \\
\hline $\mathrm{S} 2$ & $12.09 \mathrm{aA}$ & $13.62 \mathrm{aA}$ \\
\hline S3 & $6.07 \mathrm{bB}$ & $10.17 \mathrm{bcA}$ \\
\hline S4 & $5.42 \mathrm{bA}$ & $7.38 \mathrm{cA}$ \\
\hline
\end{tabular}

*Averages followed by the same letter in the column, do not differ statistically by the Tukey test $(p \leq 0,05)$. Capital letters in the lines, compare the doses of $\mathrm{P}$ for each soil; lowercase letters in the columns, compare the averages obtained for each soil.

\section{CONCLUSION}

The application of phosphorus and organic matter in degraded soils is necessary for the initial development of sorghum plants, due to the low availability of this element, caused by the high adsorption of $\mathrm{P}$ in the soil colloids.

The lack of organic matter in the studied soils led to a decrease in the growth of sorghum, therefore, it is concluded that soil management in saline environments is necessary for the application of phosphorus and organic matter for a sustainable and technically viable production.

\section{REFERENCES}

ABD EL-MAGEED, T.A.; EL-SAMNOUDI, I.M.; IBRAHIM, A.E.M.; EL TAWWAB, A.R.A. Compost and mulching modulates morphological, physiological responses and water use efficiency in sorghum (bicolor L. Moench) under low moisture regime. Agricultural Water Management, v.208, n.1, p.431-439, 2018.

ALVES, M.C.; NASCIMENTO, V.; SOUZA, Z.M. Recuperação em área de empréstimo usada para construção de usina hidrelétrica. Revista Brasileira de Engenharia Agrícola e Ambiental, v.16, n.8, p.887-893, 2012.

ANDRADE NETO, R.C.; MIRANDA, N.O.; DUDA, G.P.; GÓES, G.B.; LIMA, A.S. Crescimento e produtividade de sorgo forrageiro BR 601 sob adubação verde. Revista Brasileira de Engenharia Agrícola e Ambiental, v.14, n.2, p.124-130, 2010.
ANDRADE, F.V.; MENDONÇA, E.S.; ALVAREZ, V.H.; NOVAIS, R.F. Adição de ácidos orgânicos e húmicos em Latossolos e adsorção de fosfato. Revista Brasileira de Ciência do Solo, v.27, n.6, p.1003-1011, 2003.

BUSATO, J.G.; LIMA, L.S.; AGUIAR, N.O.; CANELLAS, L.P.; OLIVARES, F.L. Changes in labile phosphorus forms during maturation of vermicompost enriched with phosphorus-solubilizing and diazotrophic bacteria. Bioresource Technology, v.110, n.4, p.390-395, 2012.

CARSTENSEN, A.; HERDEAN, A.; SCHMIDT, S.B.; SHARMA, A.; SPETEA, C.; PRIBIL, M.; HUSTED, S. The impacts of phosphorus deficiency on the photosynthetic electron transport chain. Plant Physiology, v.177, n.1, p.271-284, 2018.

CHEN, B.; WANG, C.; WANG, P.; ZHU, Z.; XU, N.; SHI, G.; YU, M.; WANG, N.; LI, J.; HOU, J.; LI, S.; ZHOU, Y.; GAO, S.; LU, XI.; HUANG, H. Genome-wide association study for starch content and constitution in sorghum (Sorghum bicolor (L.) Moench). Journal of Integrative Agriculture, v.18, n.11, p.2446-2456, 2019. COELHO, D.S.; SIMÕES, W.L.; MENDES, A.M.S.; DANTAS, B.F.; RODRIGUES, J.A.S.; SOUZA, M.A. Germinação e crescimento inicial de variedades de sorgo forrageiro submetidas ao estresse salino. Revista Brasileira de Engenharia Agrícola e Ambiental, v.18, n.1, p.25-30, 2014. CRUZ, J.L.; COELHO, E.F.; COELHO FILHO, M.A.; SANTOS, A.L.V. Salinity reduces nutrients absorption and efficiency of their utilization in cassava plants. Ciência Rural, v.48, n.11, p.1-12, 2018. 
CUNHA, C.S.M.; HERNADEZ, F.F.F.; SILVA, F.N.; ESCOBAR, M.E.O.; MAGALHÃES, D.R.; ANJOS, D.C. Relação entre solos afetados por sais e concentração de metais pesados em quatro perímetros irrigados no Ceará. Revista Brasileira de Engenharia Agrícola e Ambiental, v.18, n.suppl., p.80-85, 2014.

EMBRAPA. EMPRESA BRASILEIRA DE PESQUISA AGROPECUÁRIA. Manual de métodos de análises de solo. 2a. ed. Rio de Janeiro: Embrapa/CNPS, 1997. 212p. GÉRARD, F. Clay minerals, iron/aluminum oxides, and their contribution to phosphate sorption in soils - a myth revisited. Geoderma, v.262, n.1, p.213-226, 2016.

KLEIN, C.; AGNE, S.A.A. Fósforo: de nutriente à poluente! Revista Eletrônica em Gestão, Educação e Tecnologia Ambiental, v.8, n.8, p.1713-1721, 2012.

LIANG, Y.; DING, Y.; WANG, P.; LU, G.; DANG, Z.; SHI, Z. Molecular characteristics, proton dissociation properties, and metal binding properties of soil organic matter: a theoretical study. Science of The Total Environment, v.656, n. 10, p.521-530, 2019.

MIRANDA, M.A.; OLIVEIRA, E.E.M.; SANTOS, K.C.F.; FREIRE, M.B.G.S.; ALMEIDA, B.G. Condicionadores químicos e orgânicos na recuperação de solo salino-sódico em casa de vegetação. Revista Brasileira de Engenharia Agrícola e Ambiental, v.15, n.5, p.484-490, 2011.

NOVAIS, S.V; NOVAIS, R.F.; ALVAREZ, V.H.; VILLANI, E.M.A.; ZENERO, M.D.O. Phosphorus-zinc interaction and iron and manganese uptake in the growth and nutrition of phalaenopsis (Orchidaceae). Revista Brasileira de Ciência do Solo, v.40, n.e0160054, p.1-10, 2016.

PARENTE, H.N.; SILVA JUNIOR, O.R.; BANDEIRA, J.R.; PARENTE, M.O.M.; RODRIGUES, R.C.; ROCHA, K.S.; GOMES, R.M.S. Produtividade do sorgo forrageiro em função de quantidades crescentes de adubação fosfatada e nitrogenada. Revista Trópica: Ciências Agrárias e Biológicas, v.8, n.1, p.1-10, 2014.

PINHEIRO, C.L.; ARAÚJO, H.T.N.; BRITO, S.F.; MAIA, M.S.; VIANA, J.S.; MEDEIROS FILHO, S. Seed priming and tolerance to salt and water stress in divergent grain sorghum genotypes. American Journal of Plant Sciences, v.2018, n.9, p.606-616, 2018.

POSSAMAI, A.J.; FREIRIA, L.B.; BARBOZA, A.C.; SILVA, P.I.J.L.R.; ZERVOUAKIS, J.T. Influência da adubação fosfatada e calagem na ecofisiologia de gramíneas forrageiras. PUBVET, v.8, n.8, p.830-974, 2014.

QIU, R.; LIU, C.; WANG, Z.; YANG, Z.; JING, Y. Effects of irrigation water salinity on evapotranspiration modified by leaching fractions in hot pepper plants. Scientific Reports, v.7, n.1, p.1-11, 2017.

SANTOS, H.G. Sistema Brasileiro de Classificação de Solos. 5a. ed. Brasília: Embrapa, 2018. 356p.

SANTOS, S.D.; SILVA, J.C.S.; LIMA, P.Q.; NETO, G.G.; CARNEIRO, M.C.; PAZ, S.M.S. Adubação e uso de cobertura morta em sorgo forrageiro. Revista Brasileira de Agropecuária Sustentável, v.6, n.3, p.1-10, 2016.
SCHOSSLER, T.R.; MACHADO, D.M.; ZUFFO, A.M.; ANDRADE, F.R.; PIAULINO, A.C. Salinidade: efeitos na fisiologia e na nutrição mineral de plantas. Enciclopédia Biosfera, v.8, n.15, p.1563-1578, 2012.

SILVA, F.A.S. ASSISTAT - Assistência Estatística versão 7.7 beta. Programa computacional. Universidade Federal de Campina Grande, Campus Campina Grande-PB - DEAG/CTRN. 2014.

SILVEIRA, T.C.; PEGORARO, R.F.; CONDO, M.K.; PORTUGAL, A.F.; RESENDE, A.V. Sorghum yield after liming and combinations of phosphorus sources. Revista Brasileira de Engenharia Agrícola e Ambiental, v.22, n.4, p.243-248, 2018.

WANG, L.; LI, Y.; PRASHER, S.O.; YAN, B.; OU, Y.; CUI, H.; CUI, Y. Organic matter, a critical factor to immobilize phosphorus, copper, and zinc during composting under various initial $\mathrm{C} / \mathrm{N}$ ratios. Bioresource Technology, v.289, n.10, p.121745, 2019. 